\title{
EKSISTENSI DAN RESISTENSI HUKUM ADAT PERKAWINAN SUKU TOLAKI DALAM ERA DIGITAL (Studi Kasus: Kabupaten Konawe Selatan)
}

\author{
Adenisatrawan \\ Email: satrawansdenis@gmail.com \\ Fakultas Syariah Institut Agama Islam Negeri (IAIN) Kendari
}

\begin{abstract}
This paper aims to analyze the existence and resistance of Tolaki tribal marriage customary law in the digital era. The research method in this paper is a qualitative method, using two approaches, namely a descriptive analytical approach and a sociological approach. The subjects in this study were the Tolaki tribal community in South Konawe Regency. Meanwhile, the informants of this study were traditional leaders, village heads and the Tolaki tribal community. Data collection is done by means of observation, documentation and interviews, then the data that has been obtained will be analyzed in depth with data analysis techniques, through processing data, reading all data, coding data, coding processes and interpreting or interpreting data to draw conclusions. Based on the results of the research and discussion, it can be explained that first, the customary law of marriage for the Tolaki tribe in South Konawe Regency still exists today, due to; 1) the progress of science and technology does not affect the implementation or implementation of the customary law of marriage for the Tolaki tribe due to a strong belief in natural punishment from rejection or neglect/stages in the implementation of the procession of marriage customs. 2) The customary law of marriage for the Tolaki tribe prioritizes the path of deliberation and is consistent with the results of deliberation decisions. 3) Religiosity in Tolaki customary law. Second; Advances in science and technology have led to changes in conditions before the marriage contract is carried out, both in terms of ideal marriages and non-ideal marriages, changes in requirements in the implementation of customary law for Tolaki tribal marriages always follow the progress of the times of economic change, but in implementation it still refers to joint decisions of the two families. bride. The meeting of two families, each represented by a trusted person, before the laying of the adat is carried out in public.
\end{abstract}

Keywords: existence, resistance, law, custom and tolaki.

\begin{abstract}
Abstrak
Tulisan ini bertujuan untuk menganalisis eksistensi dan resistensi hukum adat perkawinan suku tolaki dalam era digital. Metode penelitian pada tulisan ini adalahmetode kualitatif, dengan menggunakan dua pendekatan yakni pendekatan deskriptif analitis dan pendekatan sosiologis Subjek pada penelitian ini adalah masyarakat suku Tolaki di Kabupaten Konawe Selatan. Sedangkan Informanpenelitian ini adalah Tokoh adat, kepala desa dan masyarakat suku Tolaki. Pengumpulan data dilakukan dengan cara, observasi,
\end{abstract}


dokumentasi dan wawancara, selanjutnya data yang telah diperoleh akan dianalisis secara mendalam dengan teknik analisis data, melalui mengolah data, membaca keselurahan data, coding data, proses coding dan menginterpretasikan atau memaknai data untuk menarik kesimpulan. Berdasarkan hasil penelitian dan pembahasan dapat dijelaskan pertama, hukum adat perkawinan suku Tolaki dikabupaten konawe Selatan tetap eksis sampai sekarang, disebabkan; 1) kemajuan IPTEK tidak mempengaruhi implementasi atau pelaksanaan hukum adat perkawinan suku Tolaki dikarenakan kepercayaan yang kuat akan hukuman alam dari penolakan atau pengabaian/tahapan-tahapan dalam pelaksanaan prosesi adat istiadat perkawinan. 2) Hukum adat perkawinan suku Tolaki mengedepankan jalur musyawarah dan konsisten terhadap hasil keputusan musyawarah. 3) Religiusitas yang dimiliki dalam hukum adat Tolaki. Kedua; Kemajuan IPTEK menimbulkan perubahan syarat-syarat sebelum akad nikah dilaksanakan, baik pada persyaratan perkawinan ideal dan perkawinan tidak ideal, perubahan pada syarat dalam pelaksanaan hukum adat perkawinan suku tolaki senantiasa mengikuti kemajuan zaman perubahan ekonomi, akan tetapi dalam pelaksanaan tetap merujuk pada keputusan bersama kedua keluarga mempelai. Pertemuan dua keluarga masing-masing diwakili oleh orang kepercayaan sebelum peletakkan adat dilakukan didepan umum.

Kata kunci: eksistensi, resistensi, hukum, adat dan tolaki.

\section{Pendahuluan}

\subsection{Latar Belakang}

Hukum adat adalah istilah yang diberikan oleh kalangan ilmu pengetahuan hukum pada masa silam kepada kelompok, terhadap pedoman - pedoman dan kenyataan yang mengatur dan menertibkan kehidupan rakyat Indonesia. Kalangan ilmuwan pada waktu itu melihat bahwa rakyat Indonesia, yang hidup di pelosok- pelosok hidup dalam ketertiban dan mereka hidup tertib dengan berpedoman padaperaturan-peraturan yang mereka buat sendiri. ${ }^{1}$ Hukum adat sebagai living law bangsa Indonesia yang semakin hari semakin termarginalkan. Dalam kehidupan sehari - hari hukum adat yang semula menjadi hukum yang hidup dan mampu memberikansolusi dalam berbagai permasalahan pergaulan hidup masyarakat Indonesia. Semakin hari semakin pudar eksistensinya. ${ }^{2} \mathrm{Hal}$ tersebut tidak lepas dari kemajuan ilmu pengetahuan dan teknologi saat ini yang telah mempengaruhi segala sendi dan aktivitas kehidupan masyarakat. Kemajuan ilmu pengetahuan dan teknologi yang begitu pesat menyebabkan atau membuat perubahan dalam kehidupan sosial masyarakat, yakni tidak lagi terjadi perbedaan kultur yang sangat signifikan baik antara kultur budaya masyarakat desa dan kultur masyarakat perkotaan. Perubahan kultur masyarakat pedesaan saat ini terlihat begitu pesat pada pola gaya hidup atau lifestyle, diantaranya penggunaan handphone, media, atau kendaraan baik roda dua maupun roda empat serta tata cara dalam berpakain dan berkomunikasi masyarakat perkotaan dan pedesaan, kemajuan ilmu pengetahuan dan teknologi membuat tidak

${ }^{1}$ M. Koesnoe, (1979), Catatan-Catatan Terhadap Hukum Adat Dewasa Ini, Surabaya, Airlangga University Press, hlm 122.

${ }^{2}$ Mason C Hoadley, The Leiden Legacy: Concepts of Law in Indonesia (Review) Journal of Issues in Southeast Asia, Vol. 2 No. 1 April 2006, (Lesti Abubakar, Jurnal Dinamika hukum Revitalisasi Hukum Adat Sebagai Sumber Hukum Dalam Membangun Sistem Hukum Indonesia Vol. 13 No. 2 Mei 2013, hal. 319). 
adanya jarak Antara keduanya.

Di Indonesia, salah satu hukum yang merupakan pencerminan kepribadian bangsa adalah hukum adat, yang merupakan penjelmaan jiwa bangsa tersebut dariabad ke abad. ${ }^{3}$ Adat yang dimiliki oleh daerah-daerah adalah berbeda-beda, meskipun dasar serta sifatnya satu yaitu ke-Indonesiaannya. Oleh karena itu adatbangsa Indonesia dikatakan merupakan Bhinneka Tunggal Ika,yang artinya berbeda-beda,tetapitetap satu. Adat tersebut selalu berkembangdan senantiasa mengikuti perkembangan masyarakat dan erat hubungannya dengan tradisi rakyat. Dengan demikian adat merupakan endapan (renapan) kesusilaan dalammasyarakat,yang kebenarannya telah mendapat pengakuan umum dalam masyarakat tersebut. Berdasarkan uraian di atas, peneliti memandang perlu dilakukan pengamatan dan evaluasi, maka penelitian ini bertujuan untuk mengungkapkan eksistensi dan resistensi hukum adat perkawinan suku tolaki dalam era digital dilaksanakan.

\subsection{Rumusan Masalah}

Sebagai pijakan dan sekaligus juga sebagai pembatasan dalam pembahasan tulisan ini dikemukan rumusan masalah sebagai berikut:

1. Bagaimana eksistensi hukum adat perkawinan suku Tolaki di era di gital?

2. Bagaimana resistensi hukum adat perkawinan suku Tolaki di era digital?

\section{Metode Penelitian}

Pada penelitian ini, peneliti menggunakan metode penelitian fenomenologi dengan pendekatan kualitatif. Pendekatan kualitatif ini diartikan sebagai prosedur penelitian yang menghasilkan data deskriptif berupa kata-kata tertulis atau lisan dari orang-orang dan perilaku yang dapat diamati. Penelitian kualitatif merupakan metode-metode untuk mengeksplorasi dan memahami makna oleh sejumlah individu atau sekelompok orang, dianggap berasal dari masalah sosial atau kemanusiaan. Menurut Creswell fenomenologi merupakan salah satu jenis penelitian kualitatif, di mana peneliti melakukan pengumpulan data dengan observasi partisipan untuk mengetahui fenomena esensial partisipan dalam pengalaman hidupnya. Pendekatan kualitatif diharapkan mampu menghasilkan uraian yang mendalam tentang ucapan, tulisan, dan perilaku yang diamati dari suatu individu, kelompok, masyarakat, atau organisasi dalam suatu setting konteks tertentu yang dikaji dari sudut pandang yang utuh, komprehensif, dan holistik.

Teknik pengumpulan data yang digunakan untuk mendapatkan datadata yang dapat dipertanggungjawabkan dan bernilai validitas yang tinggi maka peneliti menggunakan wawancara, observasi dan dokumentasi. Dalam penelitian ini yang menjadi informan utama adalah ketua Adat dan kepala Desa, sedangkan yang menjadi informan pendukung adalah Sekretaris Desa, Kepala BPD, Kepala Dusun, dan Masyarakat Tolaki. Alasan pemilihan informan tersebut karena mereka terlibat langsung dalam penyelenggaraan Hukum Adat Perkawinan suku Tolaki. Di samping itu, dilakukan observasi untuk melihat secara langsung secara langsung pelaksanaan hukum perkawinan masyarakat suku Tolaki. Pengujian kredibilitas data dilakukan dengan triangulasi sumber

${ }^{3}$ Hilman Hadi Kusuma, (2007), Hukum Perkawinan Indonesia (Menurut Perundangan, Hukum Adat, Hukum Agama), Bandung, Masdar Maju, hal. 187. 
dan metode.

\section{Hasil dan Pembahasan}

\subsection{Eksistensi hukum adat perkawinan suku Tolaki di era di gital}

Saat ini hukum adat masih dalam pertumbuhan, maka tidak dapat dipungkiri adanya berbagai pendapat yang berbeda dalam memahami dan memberikan pengertian tentang hukum adat, baik dari pandangan sarjana Barat dan sarjana Indonesia. Menurut Van Vollenhoven, hukum adat adalah hukum yang tidak bersumber kepada peraturanperaturanyang dibuat oleh pemerintah Hindia Belanda dahulu atau alat-alat kekuasaan lainnya yang menjadi sendirinya dan diadakan sendiri oleh kekuasaan Belanda, dan berlaku bagi orang-orang pribumi dan orang-orang Timur Asing. ${ }^{4}$ Selanjutnyabeliau berpendapat bahwa untuk membedakan antara adat dan hukum adat adalahdilihat dari unsur sanksi, sehingga tidak semua adat merupakan hukum adat. Hanya adat yang bersanksi, yang dapat digolongkan sebagai hukum adat.

Pendapat Van Vollenhoven tersebut memperoleh tanggapan dari sarjana hukum adat yang lain, terutama karena sanksi sebagai kriteria pembeda antara adat dan hukum adat. Sanksi dalam sistem hukum barat merupakan ciri utama dari hukum, sehingga jika sanksi dijadikan sebagai satu-satunya ciri untuk membedakan antara istilah adat dan hukum adat, maka hal tersebut sangatlah tepat. Permasalahannya, sudah tepatkah kriteria sanksi tersebut dijadikan dasar untuk memahami hukum adat yang sesungguhnya.

Sejak lahir di dunia, manusia telah bergaul dengan manusia-manusia lain di dalam wadah yang disebut masyarakat. ${ }^{5}$ Dengan demikian semakin luas hubungan antara manusia tersebut kemudian dibuatlah pedoman yang merupakan aturan bagi manusia atau masyarakat tersebut. Kaidah-kaidah dan nilai-nilai yang menjadi pedoman dalam mengatur kehidupan masyarakat adalah beranekaragam. Norma hukum merupakan norma yang penting disamping norma agama, kesopanan dan kesusilaan. Norma hukum pundi dalam masyarakat beranekaragam, yang meliputi hukum tertulis dan hukum tidak tertulis. ${ }^{6}$ Setiap masyarakat diseluruh dunia mempunyai tata hukum didalam wilayah negaranya.Tidak ada suatu bangsa yang tidak mempunyai tata hukum nasionalnya. Hukum nasional bangsa merupakan cerminan darikebudayaan bangsa yang bersangkutan. Karena hukum merupakan akal budi bangsa dan tumbuh dari kesadaran hukum bangsa,maka hukum akan tampak dari cerminan kebudayaan bangsa tersebut.

Hukum Adat adalah suatu hukum yang berlaku, tumbuh dan berkembang dalam lingkungan masyarakat di suatu daerah. Hukum dapat ditemukan pada setiap masyarakat, betapapun sederhana dan kecil masyarakat itu. ${ }^{7}$ Beberapa pengertian mengenai Hukum Adat misalnya, Soepomo, Hukum Adat adalah sinonim dari hukum tidak tertulis di dalam peraturan legislatif, hukum yang hidupsebagai konvensi di badan-badan negara (parlemen, dewan Provinsi, dan sebagainya), hukum yang hidup sebagai peraturan kebiasaan yang

\footnotetext{
${ }^{4}$ Surojo Wignjodipuro, (2009)Pengantar dan Azas-Azas Hukum Adat, hlm.15,(Eka Susylawati,Jurnal Al-Ahkam, Vol IV.No. 1. Hlm. 129)

${ }^{5}$ Soerjono Soekanto, (1999), Pokok Sosiologi Hukum, Jakarta, Raja Grafindo Persada, hal, 1.

${ }^{6}$ Eka Susilawaty, Eksistensi Hukum Adat Dalam System Hukum Indoseia, (Jurna Al-Ihkam, Vol. IV, No. 1,) hlm. 126.

${ }^{7}$ Dewi C Wulansari. (2010). Hukum Adat Indonesia Suatu Pengantar. Bandung. PT. RefikaAditama, hal.34.
} 
dipertahankan dalam pergaulan hidup, baik di kota maupun di desa-desa. Menurut Hardjito Notopuro Hukum Adat adalah hukum tak tertulis, hukum kebiasaan. hal senada diungkapkan Cornelis van Vollennhoven Hukum Adat adalah himpunan peraturan tentang perilaku bagi orang pribumi dan Timur Asing pada satu pihak mempunyai sanksi (karena bersifat hukum), dan pada pihak lain berada dalam keadaan tidak dikodifikasikan (karena adat). ${ }^{7}$ Dari berbagai teori hukum adat Seorjono Sukanto mengatakan bahwa hukum yang hidup dalam masyarakat, yaitu; (1) berlaku secara yuridis, artinya pemberlakuan hukum didasarkan pada kaidah yang tingkatannya lebih tinggi, (2) berlaku secara sosiologis, artinya hukum dapat dipaksakan keberlakuannya oleh penguasa meskipun masyarakat menolaknya atau hukum berlaku karena diterima dan diakui oleh masyarakat, (3) berlaku secara filosofis, artinya sesuai dengan cita-cita hukum sebagai nilai positif yang tinggi. ${ }^{8}$ Demikian halnya dengan hukum adat perkawinan suku Tolaki bersifat tidak tertulis, dan mencakup berbagai aspek sendi keidupan suatu masyarakat dia begitu ditaati seprti Menurut hukum adat pada umumnya di Indonesia perkawinan itu bukan saja menyangkut hubungan-hubungan adat istiadatkewarisan, kekeluargaan, kekerabatan danketetanggaan serta menyangkut upacara-upacara adat dan keagamaan, dan selamat di akhirat. ${ }^{9}$

Berbagai kajian literatur tentang pertumbuhan dan eksistensi hukum adat, maka hukum adat sampai saat ini walau masyarakatnya sudah mengalami modernisasi, tetapi masyarakat tetap taat dan tunduk masing-masing pada hukum adatnya. Dengan demikian hukum adat lahir dari dan dipelihara oleh keputusan- keputusan parawarga masyarakat hukum. Lebih dari itu, keputusan-keputusan fungsionaris hukum, bukan hanya yang dihasilkan oleh hakim, tetapi juga termasuk keputusan kepala adat, rapat desa,wali tanah dan petugas- petugas desa lainnya. Keputusan tersebut juga tidak hanya yang merupakan keputusan mengenai sengketa resmi,tetapi juga meliputi keputusan yang berdasarkan nilai- nilai hidup yang berlaku dalam alam kemasyarakatan anggota-anggota persekutuan. ${ }^{10}$ Demikian halnya dengan hukum adat Tolaki, baik hukum waris adat, hukum perkawinan adatnya dan tradisi yang lainnya sampai saat ini terus terjaga, dan dilestarikan baik melalui pentas seni dan acara-acara lainnya maupun kebiasaan seharihari masyarakat Tolaki di bumi Sulawesi Tenggara, kususnyadi Kabupaten Konawe Selatan.

\subsection{Eksistensi Hukum Adat Perkawinan Suku Tolaki di Era digital}

Eksistensi hukum adat tolaki baik itu hukum adat perkawinnya dan hukumadat lainnya yang ada di Indonesia telah di lindungi Konstitusi, memerintahkan agar hukum adat, adat istiadat, kebiasaan-kebiasaan msyarakat, dan lembaga-lembaga adat yang diakui keberadaannya dan digunakan dalam kehidupan oleh masyarakat luas dan yang tumbuh berkembang di daerah-daerah, berkualifikasi sebagai nilai-nilai dan ciri-ciri budaya serta kepribadian bangsa, perlu di berdayakan, dibina dan dilestarikan. ${ }^{11}$ Dalam rangka

${ }^{8}$ Soejono Sukanto dan Mustafa Abdullah, (1987). Sosiologi hukum dalam masyarakat, Cet.III, Jakarta, Rajawali Press, hal. 13-14.

${ }^{9}$ Hilman Hadi Kusuma. (2007) Hukum Perkawinan Indonesia (Menurut Perundangan, Hukum Adat, Hukum Agama), Masdar Maju, Bandung. Hal.187

${ }^{10}$ Surojo Wignjodipuro, Pengantar dan Azas-Azas Hukum Adat, hal. 19.

${ }^{11}$ Wawancara Kepala Desa Onembute, (2019) kecamatan Palangga, kabupaten Konawe Selatan 
pemberdayaan, pembinaan, dan pemberdayaan hukum adat tersebut di perlukan informasi empirik tentang eksistensi hukum adat, khususnya dalam pemerintahan desa. Terutama perihal penerapannya, dampak penerapannya, dan kendala yang dihadapinya.

Eksistensi hukum adat tolaki baik hukum adat perkawinannya sampaiPada masa sekarang ini tumbuh dan dilaksanakan oleh masyarakat tolaki hal tersebut tidak lepas dari konfigurasi hukum yang telah berubah dan hukum adat adalah bagian organik dari hukum negara. ${ }^{12}$ Realisasi tersebut tertuang dalam Undang-Undang Nomor 4 Tahun 2004 tentang Kekuasaan Kehakiman, yang diatur di dalam pasal 25 ayat (1) yang menyatakan bahwa segala putusan pengadilan selain harus memuat alasan dan dasar putusan tersebut, memuat pula pasal tertentu dari peraturan perundang-undangan yang bersangkutan atau sumber hukum tak tertulis yang dijadikan dasar untuk mengadili. Pasal tersebut diperkuat oleh pasal 28 yang menyatakan bahwa hakim wajib menggali, mengikuti dan memahami nilai-nilai hukum dan rasa keadilan yang hidup dalam masyarakat.

Dari dua pasal tersebut di atas dapatlah ditarik kesimpulan bahwa secara implisit hukum adat dapat dijadikan dasar oleh hakim dalam mengadili danmemutus perkara di pengadilan, karena yang dimaksud sumber hukum tidaktertulis dalam pasal 25 ayat (1) adalah hukum adat. Dan yang dimaksud dengan nilai-nilai hukum dan rasa keadilan dalam masyarakat, salah satunya adalah hukum adat, dengan asumsi bahwa hukum adat adalah hukum yang tumbuh dan berkembang di masyarakat. Kedua pasal tersebut memberikan kewenangan kepada hakim dalam memutus perkara dengan mendasarkan pada hukum adat.

Keberlangsungan hukum perkawinan adat tolaki tetap eksis sampai saatini tidak lepas dari penjelasan dalam pasal 1 Undang-undang Nomor 1 Tahun 1974 tentang perkawinan dinyatakan bahwa perkawinan adalah ikatan lahir batin antara seorang pria dan seorang wanita sebagai suami istri dengan tujuan membentuk keluarga (rumah tangga) yang bahagia dan kekal berdasarkan Ketuhanan Yang Maha Esa. Untuk mencapai kebahagiaan tersebut salah satu faktor yang menentukan adalah dibutuhkan suatu kekayaan duniawi guna mencukupi keperluan hidup bersama-sama, yang nantinya akan dipergunakanoleh suami isteri untuk membiayai ongkos kehidupan mereka beserta anakanaknya. Kekayaan duniawi tersebut populer dengan istilah "harta perkawinan".

Salah satu materi hukum adat asli yang dimasukkan dalam Undang- Undang perkawinan adalah pengaturan hukum harta perkawinan. Secara garis besar dalam hukum adat parental, harta perkawinan dibagi menjadi 2 (dua) yaitu harta asal dan harta bersama. ${ }^{13}$ Pengaturan harta perkawinan menurut hukum adat tersebut kemudian dituangkan dalam pasal 35 Unda ng-Undang Perkawinan yang menyatakan bahwa harta benda yang diperoleh selama perkawinan menjadi harta bersama. Pasal tersebut dipertegas lagi oleh pasal 37 yang menyatakan bahwa bila perkawinan putus karena perceraian, harta bersama diatur menurut hukumnya masing- masing. Karenanya, di dalam praktik di masyarakat, yang dimaksud dengan hukumnya masing-masing dalam membagi harta, salah satunya adalah hukum adat tentang harta perkawinan.

12 Wawancara Kepala Desa Eewa tanggal 18 April 2019.

${ }^{13}$ Harta bersama adalah harta yang diperoleh selama perkawinan, tanpa melihat siapa yang memperoleh harta tersebut, sedangkan yang disebut sebagai harta asal/bawaan adalah harta yang diperoleh sebelum perkawinan, yang nantinya baik suami atau isteri dapat bertindak sepenuhnya untuk melakukan perbuatan hukum mengenai harta bendanya. Eka Susylawati, Jurnal Al-Ahkam, Vol. IV.No. 1 Juni 2009.h. 142 
Berdasar hal tersebut di atas pelaksanaan hukum adat perkawinan suku Tolaki tetap Eksistensi dijalankan oleh masyarakat suku tolaki di kabupaten Konawes Selatan. hukum adat perkawinan suku tolaki sampai saat ini tetap teguh dijalankan setiap masyarakat suku Tolaki dimanapun mereka berada baik suku Tolaki tersebut berada di daerah yang bukan bersuku tolaki mereka tetap menjujung tinggi dan menjalankan hukum adat perkawinan tersebut. Pengecualian terjadi, berlaku atau tidaknya hukum adat perkawinan Suku Tolaki ketika perkawinan berlangsung jika salah satunya bersuku yang bukan Tolaki, maka hukum adat perkawinan yang akan dipakai berdasarkan kesepakatan kedua keluarga mempelai. ${ }^{14}$ lebih lanjut ditegaskan oleh Kepala Desa Ululakara bahwa pelaksanaan hukum adat perkawinan Tolaki ini tidak mengalami perubahan bagi masyarakat Suku Tolaki itu sendiri kususnya didesa ini sampai saat ini sudah memasuki Era modern atau era Digital dan begitupun juga di daerah suku tolaki yang lain.

Dengan demikian eksistensi hukum adat baik hukum adat tolaki/hukum adat perkawinan tolaki hingga saat ini tetap mempunyai peranan yang penting, terutama dalam pembentukan hukum nasional yang akan datang, terutama dalam lapangan hukum kekeluargaaan. Hukum adat akan menjadi salah satu sumber utama dalam pembentukan hukum tertulis, sehingga aturan tertulis tersebut otomatis merupakan pencerminan dari hukum masyarakat. Dan tentu saja dengan harapan ketika hukum tertulis tersebut sudah diberlakukan, dalam praktik di masyarakat tidak terjadi lagi kesenjangan dengan law in action-nya.

\subsection{Resistensi Hukum Perkawinan Adat Suku Tolaki Dalam Era Modern}

Secara umum bahwa hukum adat baik hukum adat tolaki, adalah hukum yang lahir dari nilai-nilai sikap nenek moyang masyarakat tolaki yang tumbuh dan berkembang dilestarikan karena memiliki Kaidah-kaidah, nilai-nilai dan norma yang menjadi pedoman dalam mengatur kehidupan masyarakat tolaki. Suku Tolaki memilik beragam hukum adat, antara lain hukum adat perkawinan, hukum adat waris, hukum pidana adat, hukum adat meloso ako/melamar dll. ${ }^{20}$ Norma hukum dalam hukum dattolaki merupakan norma yang pentingdisamping norma agama, kesopanan dan kesusilaan. Norma hukumpun di dalam masyarakat beraneka ragam, yang meliputi hukum tertulis dan hukum tidak tertulis. ${ }^{15}$

Setiap masyarakat di seluruh dunia mempunyai tata hukum di dalam wilayah negaranya. Tidak ada suatu bangsa yang tidak mempunyai tata hukum nasionalnya. Hukum nasional bangsa merupakan cerminan dari kebudayaan bangsa yang bersangkutan. Karena hukum merupakan akal budi bangsa dan tumbuh dari kesadaran hukum bangsa, maka hukum akan tampak dari cerminan kebudayaan bangsa tersebut.

Informasi lain peneliti dapatkan yakni berdasarkan hasil wawancara bahwa resistensi atau daya tahan hukum adat perkawinan tolaki, disebabkan ketaatan masyarakat karena;1) nilai keteladanan pada tokoh adat, 2) kepercayaan berlakunya hukum alam, ketika mereka melanggar atau ingkar pada ketentuan hukum adat, 3) sebagai pembeda dengan suku yang lain, 4) Syarat bahan dalam pelaksanaan atau peletakkan hukum adat perkawinan suku Tolaki senantiasa sesuai dengan perkembangan zaman, 5) Fleksibel dalam pelaksanaan pemenuhan syarat, 6) nilai regiusitas dan 7) silaturahmi /

\footnotetext{
14 Wawancara Kepala Desa Ulu Lakara, ( 27 April 2019)

${ }^{15}$ Wawancara Ketua Adat Tanggal 25 Mei 2019
} 
kebersamaan. ${ }^{16}$

Dalam kaitannya dengan kebertahanan hukum adat Tolaki memang pada era reformasi terjadi positivisasi (pembentukan lembaga adat) lewat peraturan daerah oleh pemerintah daerah, namun itu terjadi pada tingkatan organisasi (structur) dan tidak di ikuti dengan konsolidasi yang kuat dengan aparat pengak hukum lainnya,serta tidak dikuti dengan political will penganggaraannya yang sehat, dan seakan lembaga adat itu dibiarkan berjalan seadanya, buktinya lima desa pilot project hampir sebagian besarnya tenggelam dalam ketidak pastian. Kemudian ada fenomena consensus secara alami antara lembaga penegak hukum (polsek setempat) dengan lembaga adat dalam penyelsesaiaan menyelesaian persoalan tertentu, konsensus alamiah tersebut bukan atas dasar kesadaran politik para penegak hukum, namun tidak lebih sebagai bentuk sikap pragmatis aparat yang merasa terbantu dengan eksisnya lembagaadat. Lagi pula tidak mudah bagi masyarakat agraris seperti komunitas mayarakat Donggo yang mendiami dataran tinggi untuk bisa menerima secara penuh logika hukum modern (hukum positif), dimana mereka sudah terbiasa mempertahankan tatanan adat kebiaasaan yang menjadi pemandu (a guide), pemersatu kehidupan mereka selama ini.

Daya tahan/resistensi pada hukum adat perkawinan Tolaki hingga sampai saat ini terus lestari dilaksanakan oleh masyarakat Tolaki adalah terletak pada sifat ketaatan masyarakat Tolaki pada hukum adatnya, kepercayaan dan keyakinan kebenaran hukum adat yang dilaksanakan akan membawah berkah. ${ }^{17}$ dalam wawancara dengan informan yang lain, dijelaskan resistensi pada hukum adat perkawinan Tolaki terletak pada kemudahan masyarakat melaksanakan hukum adat perkawinan tolaki dalam hal pemenuhan syarat, dan kekuatan magis yang dipercaya oleh masyarakat Tolaki jika rtidak taat padahukum adat maka akan mendapatkan sanksi alam.

Proses perkawinan bagi masyarakat Tolaki memiliki makna yang sangat penting, yang sarat dengan nilai-nilai, baik nilai sosial, kultural, maupun religius. Kekhasan dalam system perkawinan suku Tolaki, sangat tampak melalui perwujudan dalam praktek dan penghayatan perkawinan berkaitan dengan sosial, kultural dan religius. Dari segi sosial perkawinan pada masyarakat suku Tolaki sering disebut "Mesarapu"yang berarti merumpun. Merupakan suatu persekutuan rumpun antarasatu keluarga dengan keluarga lainnya. Dari segi kultural perkawinan "perapua" dimasyarakat Tolaki meliputi suatu tata cara dan tata acuan yang rumit tampil sistimatika. Perkawinan adat ini diwariskan secara turun temurun yang disebut masyarakat hukum adat dengan adat Kalo Sara sebagai "Urat Nadi Hukum Adat Tolaki, begitu pula dala tatanan kehidupan Tolaki dikenal Kalo Sara sebagai karakter dan jati diri suku bangsa Tolaki. ${ }^{18}$

Seperti yang telah di uraikan, dari segi cultural, perkawinan "perapua" meliputi tata cara dan tata acuan yang rumit dan tampil secara sistimatis yaitu prosesi penyelenggaran perkawinan adat tolaki yang terdiri dari lima tahap dengan rangkaian isi adat. Jika dahulu pelaksanaan harus melalui sesuai tahapan yang mana tidak boleh melangkahi satu tahapan prosesi perkawinan tersebut. Namun dengan perkembangan dan kemajuan zaman, dimana berperannya teknologi komunikasi dan informasi dewasa ini, ternyata tahapan tersebut

\footnotetext{
${ }^{16}$ Wawancara Kepala Dusun tanggal 25 Mei 2019

17 Wawancara Sekdes tanggal 25 Mei 2019

${ }^{18}$ Wawancara Muliadin, masyarakat Desa Ulu Lakara Tanggal 21 Mei 2019.
} 
dapat menyesuaikan dan menyederhanakan pelaksanaannya.

Dalam pelaksanaan tahapan-tahapan pernikahan, membutuhkan waktu yang tidak singkat. Untuk menuju pada tahap mowindahako dibutuhkan waktu agak panjang, bahkan ada yang membutuhkan waktu sampai satu tahun atau lebih, karena harus mempersiapkan benda adat yang nantinya akan menjadi seserahan juga untuk mempersiapkan biaya pesta. Sehingga normalnya apabila mengikuti tahap-tahap adat ini akan membutukan waktu antara empat sampai enam bulan.

Menurut hemat penulis, dari uraian di atas dapat disimpulkan bahwa pernikahan pada suku tolaki hingga kini masih mengikuti prosesi maupun tahapanyang ada secara turun temurun. Akan tetapi dalam pelaksanannya mengikuti perkembangan dan kebutuhan manusia. Contohnya penggunaan benda adat, walaupun benda tersebut tidak lagi ditampilkan, tetapi digantikan dengan materi (uang) sesuai dengan nilai yang telah ditentukan berdasarkan hasil musyawarah mufakat (kesepakatan bersama).Maka, Dengan berubahnya benda adat ritual dalam pernikahan yang digunakan, secara langsung terjadi pergeseran nilai. Terdapat dua Dan faktor penyebab terjadinya pergeser tersebut yaitu faktor internal efesiensi waktu dan efesiensi biaya sedangkan faktor eksternal dengan masuknya budaya ekonomi politik media yang lambat laun dapat menggantikan nilai asli benda adat tersebut.

Dengan demikian, apabila dilihat dari segi sosial faktor tersebut merupakan hal positif yang mempermudahkan prosesi pernikahan, terutama dari kalangan masyarakat yang taraf kehidupannya pas-pasan, namun lain halnya dari segi budaya dimana dengan adanya faktor pergeseran nilai ini akan mengikis nilai-nilai budaya yang menjadi ciri khas suku tolaki dalam prosesi pernikahan, bahkan lambat laun akan hilang dengan sendirinya dan generasi muda suku tolaki tidak akan memahami nilai benda adat yang digunakan. Perubahan benda-benda adat di atas dalam melaksanakan penyeragaman berdasarkan keadaan yang berada pada masyarakat dalam pelaksanaan pernikahanyang bervariasi, sehingga melalui musyawarah mufakat dari berbagai elemen terkait, maka terjadilah penyeragaman dalam menentukan pokok adat.

Dari hasil musyawarah mufakat maka telah disepakati jumlah nilai benda yang akan digantikan dengan materi, begitu pula dengan besarnya ongkos biaya pesta yang akan ditanggung oleh pihak keluarga laki-laki.Seperti yang dikemukakan sebelumnya Besaran jumlah ongkos biaya pesta yang telah disepakati sebelumnya ini dipengaruhi oleh status sosial yang melekat pada orang akan melaksanakan pernikahan baik dari pihak lakilaki maupun dari pihak perempuan, tingkat pendidikan, strata sosial ,dan apalagi jika orang tersebut keturunan anakia ( bangsawan), semakin tinggi derajat status tersebut maka semakin tinggi pula ongkos biaya pestanya, tetapi hal tersebut tidak mempengaruhi jumlah nilai tukar benda adat seserahan berdasarkan kesepakat penyeragaman persyaratan pelaksanaan pernikahan Orang Tolaki. Bahkan hal persyaratan utama yang menjadi pembahasan pada peminangan sebelum melangsungkan perkawinan adalah besaran pokok adat, jumlah mahar (popolo), dan sara peana,dari ketiga pokok adat adalah bendabenda dan ongkos biaya pesta yang akan diberikan, pihak laki-laki ke pada pihak calon mempelai perempuan. 
Perkembangan masyarakat menyebabkan adanya pergeseran nilai dari beberapa benda yang terdapat dalam upacara pernikahan suku tolaki. Pelaksanaan upacara adat pernikahan yang didalamnya terdapat benda-benda adat hanyaalah bersifat mneruskan tradisi yang sudah ada, karena tradisi yang ada pada masyarakat tidaklah mudah untuk dihapuskan. Masyarakat tidaklah megerti akan makna yang terkandung dalam bendabenda adat yang ditampilkan. Masyarakat tidaklah mengerti bahwa budaya asing yang masuk menyusup ke dalam budaya asli sebenarnya memiliki dampak bergesernya nilai budaya tersebut. Masyarakat hanya menilai jika perubahan itu bersifat baik (positif),maka masyarakat dapat menerimanaya dan bukaanlah hal yang dipertentangkan pada kalangan massyarakat. Alasan agar budaya perlu dipertahankan maka terkadang unsur dari luar yang cocok dengan nilai dan kepercayaan yang ada atau hal-hal yang dapat dimodifikasi tanpa menyebabkan gangguan adaptasi.

Komodifikasi pergeseran nilai dalam upacara adat pernikahan suku tolaki terjadi berdasarkan atas hasil musyawah mufakat denga nkesepakatan bersama antara tokoh adat, Puutobo dan Pabitara dari berbagai Kabupaten yang bersangkutan di Sulawesi Tenggara dengan tujuan guna penyeragaman dalam pemenuhan benda-benda adat yang di tampilkan dalam pelaksanaan upacara pernikahan. Ada pun hasil musyawarah mufakat yaitu sebagai berikut:

a. Puuno Sara yang artinya isi pokok adat yang terdiri dari seekor kerbau, sebuah gong, emas perhiasan wanita yang dapat digantikan dengan uang senilai $\mathrm{Rp}$ 50.000,- dan terkecuali kain kaci yang tetap ditampilkan.

b. Tawa Sara artinya daun adat yang terdiri dari 40 buah sarung adat.

c. Ihino Popolo artinya mahar pernikahan yang terdiri seperangkat alat sholat sebagai mas kawin serta biaya pesta.

d. Sara Peena, artinya benda simbol pengganti jasa ibu dalam merawat anaknya yang terdiri dari Rane-Rane Mba'a (1 lembar sarung), Tema-Temano (1 lembar kain panjang), Boku Mbebahoa (1 buah baskom), Sandu-Sanduno (1buah timba-timba air), Siku-Siku Hulono (1buah lampu tembok).

Selain itu, Terdapat dua faktor penyebab terjadinya pergeseran yaitu faktor internal yang terdiri dari efesiesi waktu, efesiensi biaya sedangkan faktor eksternalnya maraknya budaya politik ekenomi media. Sehingga berdampak kurangnya kesakralan dalam pelaksanaan upacara pernikahan Suku Tolaki dan lambat laun nilai -nilai yang terkandung akan terkikis oleh kemajuan zaman. Bagi masyarakat pada umumnya dampak perubahan yang terjadi dalam system adat Pernikahaan Suku Tolaki merupakan hal yang positif dan tidak dipertentangkan pada kalangan masyarakat. Hal ini dikarenakan tingkat kehidupan masyarakaat yang beragam, bagi mereka yang tergolong mampu perubahan ini tidaklah terlalu berpengaruh, namun bagi mereka yang tingkat kehidupannya sedang-sedang maka perubahan ini sangatlah menguntungkan.

\section{Kesimpulan}

Hukum adat perkawinan suku Tolaki tetap Eksis dijalankan oleh masyarakat suku tolaki di kabupaten Konawes Selatan. hukum adat perkawinan suku tolaki sampai 
saat ini tetap teguh dijalankan setiap masyarakat suku Tolaki dimanapun mereka berada baik suku Tolaki tersebut berada di daerah yang bukan bersuku tolaki mereka tetap menjujung tinggi dan menjalankan hukum adat perkawinan tersebut. Pengecualian terjadi, berlaku atau tidaknya hukum adat perkawinan Suku Tolaki ketika perkawinan berlangsung jika salah satunya bersuku yang bukan Tolaki, maka hukum adat perkawinan yan akan dipakai berdasarkan kesepakatan kedua keluarga mempelai. Sehingga sampai saat hukum adat pernikahan pada suku tolaki hingga kini masih mengikuti prosesi maupun tahapan yang ada secara turun temurun. Akan tetapi dalam pelaksanannya mengikuti perkembangan dan kebutuhan manusia. Resistensi pada hukum adat perkawinan suku Tolaki terletak pada kandungan makna yang sangat penting, yang sarat dengan nilai-nilai, baik nilai sosial, kultural, maupun religius. Kekhasan dalam system perkawinan suku Tolaki, sangat tampak melalui perwujudan dalam praktek dan penghayatan perkawinan berkaitan dengan sosial, kultural dan religius.

\section{Daftar Pustaka}

\section{A. Buku}

Margono, (2019). Asas Keadilan, Kemanfaatan dan Kepastian Hukum Dalam Putusan Hakim. Jakarta: Sinar Grafika.

Nasarudin, M.I, dkk. (2004). Aspek Hukum Pasar Modal Indonesia. Jakarta: Kencana.

Wijaya, A. dan Ananta, W.P. (2018). IPO, Right Issue dan Penawaran Umum Obligasi. Jakarta: Sinar Grafika.

Ammidhan, dan Saafudin (Penanggung Jawab). (2006), Mewujudkan Hak Konstitusional Mayarakat Hukum Adat. Jakarta: Komnas HAM

Dewi C Wulansari. (2010). Hukum Adat Indonesia Suatu Pengantar. Bandung. PT. Refika Aditama.

Bagong Sutopo, (2005). Metode Penelitian Kualitatif. Suarakarta. Universitas Negeri Sebelas Maret,

Koesnadi Hardjasoemantri, (2002) Hukum Tata Lingkungan Cet. Ke-17, Ed. Ke-7, Yogyakarta: Gajah Madah University Press.

Lexi J Maleong, (2007). Metode Penelitian Kualitatif. Bandung, PT. Remaja Rosda Karya. Lexi J Maleong, (2010). Metode Penelitian Kualitatif.Edisi Revisi. Bandung: Penerbit PT Remaja Rosda Karya.

Miles Dan Huberman, (2004). Qualitative Data Analysis (Terjemahan). Jakarta: UI Press. Phillipe Sands, (2003). Principles Of International Environmental Law, and edition, Cambrige: Cambridge University Press.

Suharsimi Arikunto, (2004). Prosedur Penelitian Suatu Pendekatan Praktek. Edisi Revisi V. Jakarta: Rineka Cipta.

Sugiyono, (2011). Metode Penelitian Kuantitatif, Kualitatif, Dan Kombinasi. Mixed Methods. Bandung. Alfabeta.

\section{B. Peraturan Peundang-undangan}

Undang-undang Nomor 1 Tahun 1974 tentang perkawinan

\section{Artikel Jurnal}

Santoso, (2016). Hakekat perkawinan menurut undang-undang perkawinan, hukum Islam dan hukum adat, jurnal pemikiran dan penelitian sosial keagamaan, $7(2)$. 
Adharinalti. (2012), Eksistensi Hukum Adat dalam Penyelenggaraan Pemerintahan Desa di Bali". Jurnal RechtsVinding Jakarta: Badan Pembinaan Hukum Nasional, 1(3).

Eka Susylawati, (2009), Eksistensi Hukum Adat dalan Sistem Hukum di Indonesia". eJiurnal Al Ihkam: Jurnal Hukum dan Pranata Sosial. Volume IV (1). 